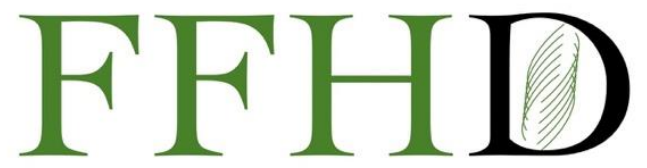

Functional Foods in Health and Disease

\title{
Effect of flavonoid-rich meals and low-flavonoid meals based on the dietary reference intakes for Japanese, using basic foodstuffs on the gene expression of inflammatory cytokines in the whole blood cells from adult men of normal or light overweight
}

\author{
Ryo Mannen ${ }^{1}$, Michiko T. Yasuda ${ }^{2}$, Ayami Sano ${ }^{3}$, Toshinao Goda ${ }^{1}$, \\ Kayoko Shimoi ${ }^{1}$, Yoko Ichikawa ${ }^{1 *}$
}

${ }^{1}$ Graduate School of Integrated Pharmaceutical and Nutritional Sciences, University of Shizuoka, Yada 52-1, Surugaku, Shizuoka 422-8526, Japan; ²Department of Human Nutrition, School of Life Studies, Sugiyama Jogakuen University, 17-3 Hoshigaoka Motomachi, Chikusa-ku, Nagoya 464-8662, Japan; ${ }^{3}$ Department of Health and Nutritional Sciences, Faculty of Health Promotional Sciences, Tokoha University, 1230 miyakodacho Kita-ku, Hamamatsu, Shizuoka, 4312102, Japan.

Corresponding author: Yoko Ichikawa, PhD, Graduate School of Integrated Pharmaceutical and Nutritional Sciences, University of Shizuoka, Yada 52-1, Suruga-ku, Shizuoka 422-8526, Japan

Submission Date: January 26 $6^{\text {th }}, 2021$; Acceptance Date: February 18 ${ }^{\text {th }}, 2021$; Publication Date: February $26^{\text {th }}, 2021$

Please cite this article as: Mannen R., Yasuda M., Sano A., Goda T., Shimoi K., Ichikawa Y. Effect of flavonoid-rich meals and low-flavonoid meals based on the dietary reference intakes for Japanese using basic foodstuffs on the gene expression of inflammatory cytokines in the whole blood cells from adult men of normal or light overweight. Functional Foods in Health and Disease 2021. 11(2): 56-72. DOI: https://www.doi.org/10.31989/ffhd.v11i2.781

\footnotetext{
ABSTRACT

Introduction: Flavonoids have a variety of functions, such as antioxidant activity, and are expected to have a disease prevention effect. In order to verify the disease risk reduction effect of flavonoids, we carried out a crossover trial in seven adult men of normal or light overweight who ingested flavonoid-rich meals, with a diverse combination of basic foodstuffs, and low-flavonoid meals and compared blood disease-related inflammatory markers.
}

Methods: On the first two days of the study, seven male volunteers were provided with low-flavonoid meals (flavonoid content below the detection limit of HPLC: less than $0.24 \mathrm{mg} / \mathrm{meal}$ ) three times a day as a washout. 
For the next seven days, they were fed flavonoid-rich meals $(46.9 \pm 8.1 \mathrm{mg} / \mathrm{meal})$ or lowflavonoid meals. Blood samples were collected from all the volunteers before breakfast on the third day, after the washout and before breakfast on the tenth day. The test was consisted of one cycle from the first day to the tenth day, and the participants

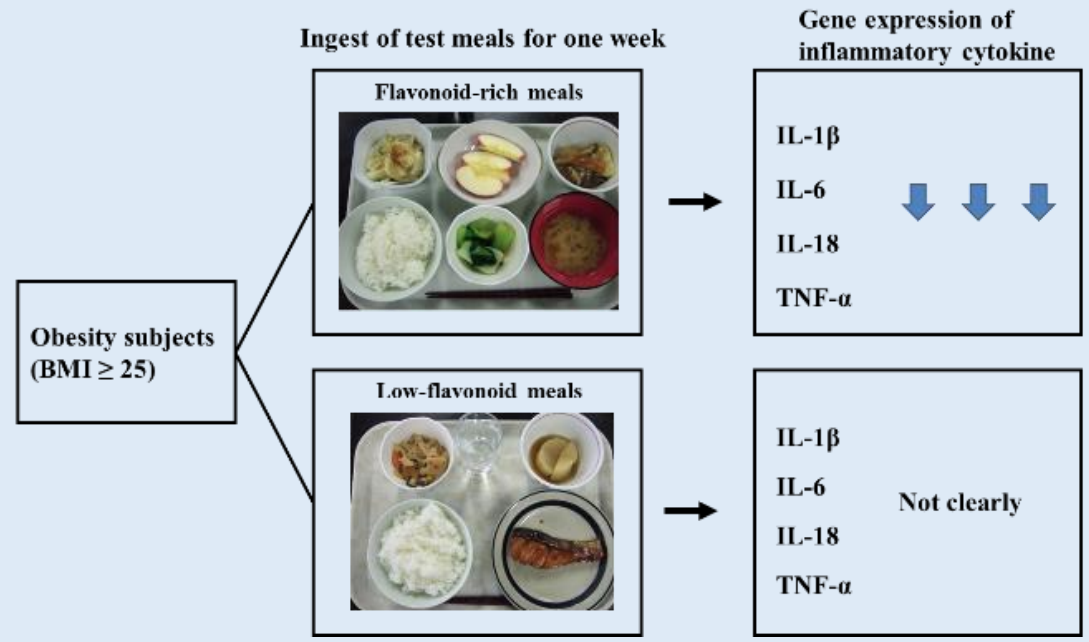
carried out two cycles. Flavonoid concentrations in plasma and gene expression of inflammatory cytokine (interleukin 1 beta, interleukin 6, interleukin 18, and tumor necrosis factor- $\alpha$ ) in whole blood cells were compared before and after the intervention. Gene expression in whole blood cells was measured using real time RT-PCR.

Results: We found a significant increase in plasma flavonoid concentration (quercetin, kaempferol, daidzein, and genistein) upon intervention with flavonoid-rich meals $(p<0.05)$. In addition, the inflammatory cytokine gene expression was reduced in the subjects with a body mass index of more than, but not less than, $25 \mathrm{~kg} / \mathrm{m}^{2}$ compared with that observed after the intake of low-flavonoid meals.

Conclusion: These results suggest that flavonoid-rich meals have an anti-inflammatory effect in obese persons who are likely to have chronic inflammation.

Keywords: Flavonoids, inflammatory cytokines, flavonoid-rich meal, human study

CFFC 2021. This is an Open Access article distributed under the terms of the Creative Commons Attribution 4.0 License (http://creativecommons.org/licenses/by/4.0)

\section{INTRODUCTION}

Flavonoids, found in many vegetables and fruits, are a type of polyphenol and are categorized into the following classes based on their aglycone structures: flavonols, isoflavones, flavones, flavanols, anthocyanins, and flavanones. They exist as glycosides in plants, and approximately 9,000 types of flavonoid glycosides have been reported to date [1].

In a cohort study of Dutchmen, there was a significant reduction in coronary heart disease risk in high-flavonoid intake groups compared with that in low- flavonoid intake groups [2]. Dietary flavonoids are thought to have potentially beneficial effects in preventing various diseases such as heart disease and obesity [3-5]. Furthermore, many studies have been conducted on other in vivo functions, and various effects have been elucidated to date, such as antioxidant and anti-inflammatory effects in animal studies and insulin resistance improvement in human studies [6-8]. In particular, postprandial hyperglycemia activates the leukocytes through the production of reactive oxygen species (ROS) by activated neutrophils 
and enhanced glucose metabolism in mitochondria [9]. The activated leukocytes secrete inflammatory

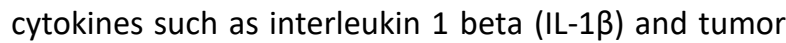
necrosis factor- $\alpha$ (TNF- $\alpha) \quad[10,11]$. Thus, disease prevention benefits due to the bioactivities of flavonoids are expected, and there have been developments and market growth in the food industry focusing on the health-promoting benefits of flavonoids. Regarding the anti-inflammatory effects of flavonoids, it has been reported that quercetin glycosides decreased the formation of nitrotyrosine, an inflammatory marker, in both rats and humans [12,13]. On the other hand, Azuma et al. [14] conducted a comparative study in which stress-burdened rats were fed quercetin supplement or onion, including equal amounts of quercetin aglycone to that of the supplement. They found that the levels of thiobarbituric acid reactive substances, which are oxidation markers, were lower in the group fed with onion than in that fed with quercetin supplement. These results indicate that ingesting flavonoidcontaining foods may have antioxidant and antiinflammatory effects. In addition, the Academy of Nutrition and Dietetics recommends combining a variety of basic foodstuffs, rather than a single type of food, nutrient, supplement, or functional ingredient (Total Diet Approach) [15]. Based on these reports, it is important to consider the efficacy of intaking flavonoids from a meal rather than a supplement. On the other hand, interventional studies using supplements on the anti-inflammatory effects of flavonoids have been conducted by Zahedi et al. [16] and Boots et al. [17], but to our knowledge, there are few reports that have investigated in the meal.

In this study, we focused on quercetin, kaempferol, daidzein, and genistein contained in many foods and conducted crossover human trial using flavonoid-rich or low meals based on the dietary reference intakes (DRIs) for the Japanese with a diverse combination of basic foodstuffs to examine the disease risk reduction effect of continuous intake of flavonoids from meals. We determined the flavonoid concentrations in plasma and its excretion in urine when continuously ingesting the flavonoid-rich or low meals by combining a variety of basic foodstuffs. The effect of flavonoid intake on inflammatory cytokine gene expression in whole blood cells was also examined with reference to Cristina et al. [18] and Huang et al. [19].

\section{METHODS}

Test meals: We established a flavonoid-rich meal, as previously described [20]. Briefly, Hertog et al. [2] and Knekt et al. [21] reported that flavonoid intake was 25.9 $\mathrm{mg} /$ day and $3.4 \mathrm{mg} /$ day for Dutch and Finnish, respectively. Arai et al. [22] reported a flavonoid intake of $63.9 \mathrm{mg} /$ day (flavonols and flavones: $16.7 \mathrm{mg} /$ day, isoflavones: $47.2 \mathrm{mg} /$ day) in 117 of healthy Japanese people. Therefore, it is estimated that the flavonoid intake in this Japanese population was $21.3 \mathrm{mg} / \mathrm{meal}$ (flavonols and flavones: $5.6 \mathrm{mg} / \mathrm{meal}$; isoflavones: 15.7 $\mathrm{mg} / \mathrm{meal}$ ). The flavonoid-rich meal in this study was made with basic foodstuffs, referring to the reported flavonoid content of each foodstuff, and prepared to contain more flavonoids than the $21.3 \mathrm{mg} / \mathrm{meal}$ reported above.

Three factors were considered in formulating the flavonoid-rich meals: (1) they should satisfy nutrition requirements based on the DRIs for the Japanese (2015) [23] including $\mathrm{Zn}, \mathrm{Cu}, \mathrm{Mg}, \mathrm{K}, \mathrm{Na}$, Vitamins $\mathrm{K}$ and D; (2) they should comprise flavonoid-rich basic foodstuffs; and (3) they should be modeled after typical Japanese meals, which comprise a staple food, main dish, side dish, and soup. The nutritional value of the meal was calculated using the Standard Tables of Food Composition in Japan, Seventh edition (2015) [24] (Table 1). 
Table 1. The average nutritional value of the test meal

\begin{tabular}{|c|c|c|c|c|c|c|c|c|c|c|c|c|c|}
\hline Meal type & Energy & Protein & Fat & Carbohydrate & Calcium & Iron & $\begin{array}{c}\text { Retinol } \\
\text { equivalent }\end{array}$ & $\begin{array}{c}\text { Vitamin } \\
\text { B1 }\end{array}$ & $\begin{array}{c}\text { Vitamin } \\
\text { B2 }\end{array}$ & $\begin{array}{c}\text { Vitamin } \\
\text { C }\end{array}$ & $\begin{array}{c}\text { Vitamin } \\
\text { E }\end{array}$ & $\begin{array}{l}\text { Total } \\
\text { dietary } \\
\text { fiber }\end{array}$ & $\begin{array}{c}\text { Salt } \\
\text { equival } \\
\text { ents }\end{array}$ \\
\hline & kcal & $g$ & g & g & $\mathrm{mg}$ & $\mathrm{mg}$ & $\mu \mathrm{g}$ & $\mathrm{mg}$ & $\mathrm{mg}$ & $\mathrm{mg}$ & $\mathrm{mg}$ & $\mathrm{g}$ & $\mathrm{g}$ \\
\hline $\begin{array}{c}\text { Flavonoid- } \\
\text { rich }\end{array}$ & 688 & 27.9 & 18.2 & 100 & 1019 & 5.8 & 169 & 0.53 & 0.29 & 27 & 1.6 & 5.2 & 3.6 \\
\hline $\begin{array}{l}\text { Low- } \\
\text { flavonoid }\end{array}$ & 624 & 24.0 & 12.8 & 101 & 981 & 2.3 & 216 & 0.25 & 0.32 & 20 & 2.5 & 8.1 & 2.4 \\
\hline
\end{tabular}

These values were averages for menu No. 1 to 9, respectively.

The nutritional value of the meal was calculated using the Standard Tables of Food Composition in Japan, Seventh edition (2015).

The low-flavonoid meals that were ingested as part of the washout procedure used in this study were modified from those used in the study by Sakakibara et al. [25]. Like the flavonoid-rich meals, these lowflavonoid meals are based on DRIs for the Japanese population (2015) [24] and take into account energy and nutrients (Table 1). The flavonoid content of the low-flavonoid meals was below the detection limit of high-performance liquid chromatography (HPLC).

Chemicals: Quercetin, kaempferol, apigenin, luteolin, naringenin, daidzein, genistein, flavone, and robinetin were procured from Extrasynthese (Genay, France). In general, as flavonoids are present as individual glycosides in plants enzyme treatment to samples of meal, plasma and urine is needed to convert conjugate to aglycone. In this study, $\beta$-Glucosidase (from almonds, G0395) was used for meal samples and $\beta$ Glucuronidase (from Helix pomatia, type H-5, G1512) was used for plasma and urine samples for this purpose. In addition, the amount of flavonoids in this study was used the total amount of what converted to aglycone by treating the plasma, urine and meal with a deconjugated enzyme treatment. $\beta$-Glucosidase and $\beta$ Glucuronidase were purchased from Sigma Aldrich (St. Louis, MO, USA). All other chemicals used in the study were of liquid chromatography- tandem mass spectrometry (LC-MS) or HPLC grade. The food materials used to prepare the meals were purchased from a local supermarket.

Study design: The study protocol was approved by the Ethics Committee of the University of Shizuoka (permission number 26-12). The subjects were seven male volunteers, aged $36.6 \pm 8.4(26-50)$ years, body mass index (BMI) $26.4 \pm 3.7(21.0 .32 .6) \mathrm{kg} / \mathrm{m}^{2}$, who gave informed consent (Table 2). We divided four people (No. 1 - No. 4) with a $\mathrm{BMI}<25 \mathrm{~kg} / \mathrm{m}^{2}$ into the normal group and three people (No. 5 - No. 7) of $\geq 25 \mathrm{~kg} / \mathrm{m}^{2}$ into the obesity group. The subjects had to be at least 18 years old and not been taken any medication or supplements. The participants were asked to refrain from eating or drinking anything other than the test meals and water during the study period. The test consisted of one cycle from the first day to the tenth day, and the participants had flavonoid-rich and low-flavonoid meals, one cycle, for a total of two cycles (Fig 1 and Table 3).

On the first two days of the study, the participants were provided with low-flavonoid meals three times a day as a washout. For the next seven days, they were fed flavonoid-rich meals or low-flavonoid meals.

Estimation of daily nutrition intake: We analyzed the daily nutrient intake of participants using the Food Frequency Questionnaire Based on Food Groups (FFQg) (Excel Eiyoukun FFQg, version 4.0, Kenpakusha, Tokyo, 
Japan) [26]. The FFQg is the questionnaire that can be used to calculate the daily intake of nutrients by asking participants to answer the frequency of food intake in the past a month. We analyzed the answers for this questionnaire to estimate the daily nutrients intake of participants.

Extraction of meals and HPLC analysis: Flavonoid-rich

Table 2. Physical condition of the subjects

\begin{tabular}{|c|c|c|c|c|c|}
\hline Subject number & Age & Height $(\mathrm{cm})$ & Body weight (kg) & BMI (kg/m2) & Group \\
\hline No,1 & 47 & 173.0 & 73.0 & 24.4 & normal \\
\hline No,2 & 33 & 169.0 & 67.0 & 23.5 & normal \\
\hline No,3 & 34 & 168.0 & 70.3 & 24.9 & normal \\
\hline No,4 & 50 & 166.0 & 58.0 & 21.0 & normal \\
\hline No,5 & 28 & 184.0 & 103.0 & 30.4 & Obesity \\
\hline No,6 & 26 & 176.0 & 101.2 & 32.6 & Obesity \\
\hline No,7 & 38 & 178.6 & 86.0 & 27.0 & Obesity \\
\hline Mean \pm SD & $36.6 \pm 8.4$ & $173.5 \pm 6.0$ & $80.2 \pm 15.9$ & $26.4 \pm 3.7$ & \\
\hline
\end{tabular}

$\mathrm{n}=7$; The subjects are indicated by No.1 to No.7. No.1 to No.4 with BMI $<25 \mathrm{~kg} / \mathrm{m}^{2}$ comprised the normal group, and No.5 to No.7 with $\mathrm{BMI} \geq 25 \mathrm{~kg} / \mathrm{m}^{2}$ comprised the obesity group.

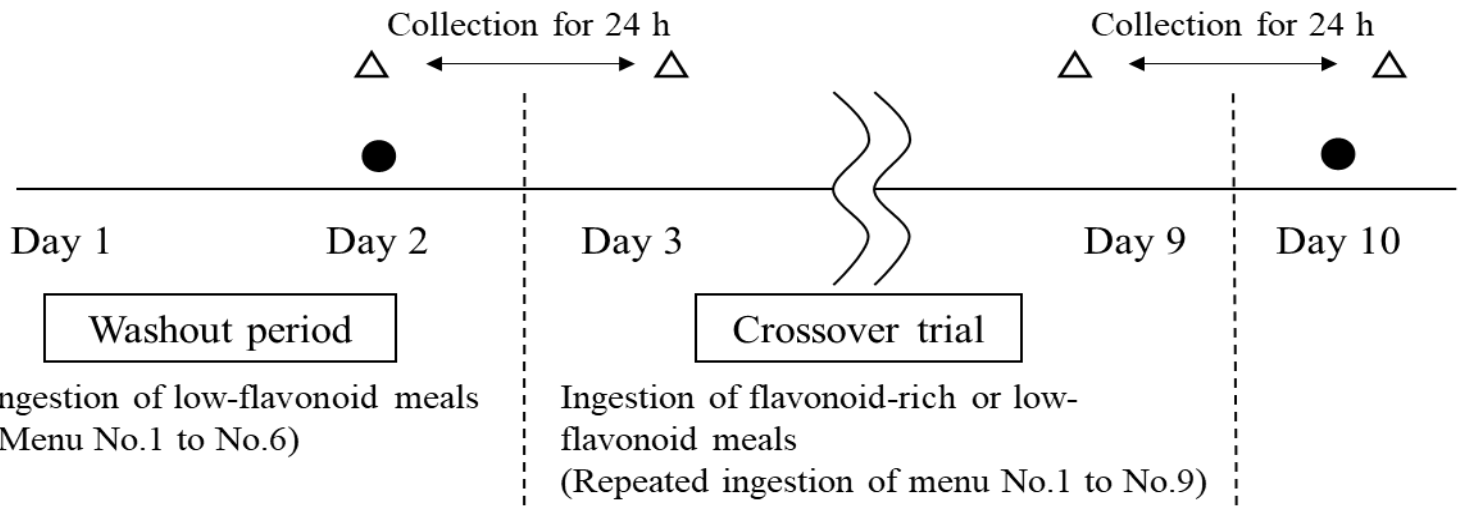

: Blood collected : 9:00 a.m. before breakfast

$\triangle:$ Urine collected : 24 hours from 9:00 a.m. before breakfast

Figure 1. Design of the study. 
Table 3. Design of test meal

\begin{tabular}{|c|c|c|c|c|}
\hline \multirow[t]{2}{*}{ Day } & \multicolumn{2}{|c|}{ Flavonoid rich group } & \multicolumn{2}{|c|}{ Flavonoid poor group } \\
\hline & Meal type & Menu Number & Meal type & Menu Number \\
\hline 1 & Low & $1,2,3$ & Low & $1,2,3$ \\
\hline 2 & Low & $4,5,6$ & Low & $4,5,6$ \\
\hline 3 & Rich & $1,2,3$ & Low & $1,2,3$ \\
\hline 4 & Rich & $4,5,6$ & Low & $4,5,6$ \\
\hline 5 & Rich & $7,8,9$ & Low & $7,8,9$ \\
\hline 6 & Rich & $1,2,3$ & Low & $1,2,3$ \\
\hline 7 & Rich & $4,5,6$ & Low & $4,5,6$ \\
\hline 8 & Rich & $7,8,9$ & Low & $7,8,9$ \\
\hline 9 & Rich & $1,2,3$ & Low & $1,2,3$ \\
\hline
\end{tabular}

Rich: flavonoid-rich meals; Low: low-flavonoid meals

$(\mathrm{pH} 4.6)$ for $4 \mathrm{~h}$ at $37^{\circ} \mathrm{C}$. Flavone (final concentration $0.05 \mu \mathrm{mol} / \mathrm{L})$ was added to the sample as an internal standard. Samples were then mixed with $6 \mathrm{~mL}$ methanol for 1 min using a vortex mixer. The mixture was then centrifuged at $3000 \times g$ at $4^{\circ} \mathrm{C}$ for $10 \mathrm{~min}$. The supernatant was collected and the pellet was reextracted three times using $2 \mathrm{~mL}$ of $90 \%$ methanol in water. The methanol supernatants were combined and reduced to dryness in vacuo. The dried extract was further dissolved in $1 \mathrm{~mL} 0.5 \%$ trifluoroacetic acid (TFA) in methanol, before centrifugation at $15,000 \times g$ at $4^{\circ} \mathrm{C}$ for $10 \mathrm{~min}$. Subsequently, the supernatant was analyzed using a UV detector (G4303A; Agilent Technologies Inc., Santa Clara, CA, USA) connected to an Agilent 1200 HPLC apparatus (Agilent Technologies Inc., Santa Clara, CA, USA) using a C18 column (particle size, $2.7 \mu \mathrm{m}$; dimensions, $2.1 \times 150 \mathrm{~mm}$; Agilent Technologies Inc., Santa Clara, CA, USA). The flavonoids measured were quercetin, kaempferol, daidzein, genistein, and flavone. In addition, apigenin, luteolin, and naringenin were measured because they may have been detected in previous studies $[2,21,22]$. The detection limits for these flavonoids were $0.1 \mu \mathrm{mol} / \mathrm{L}$. A gradient program using solvent $A(0.1 \%$ formic acid $)$ and solvent $B$ (acetonitrile) was used at a flow rate of $0.6 \mathrm{~mL} / \mathrm{min}$. The gradient program was as follows: 0-2.5 min, linear gradient from $5 \%$ to $15 \% \mathrm{~B} ; 2.5 .2 .51 \mathrm{~min}$, linear gradient to $20 \%$ B; $2.51 .20 \mathrm{~min}$, hold $20 \%$ B; $20-25 \mathrm{~min}$, linear gradient to $100 \% \mathrm{~B} ; 25-26 \mathrm{~min}$, linear gradient to $5 \% \mathrm{~B}$; and $26-29 \mathrm{~min}$, hold $5 \% \mathrm{~B}$.

Plasma extraction and LC/MS analysis: The blood samples for plasma were centrifuged at $1,000 \times g$ at $4^{\circ} \mathrm{C}$ for $20 \mathrm{~min}$, and the supernatants were stored at $-80^{\circ} \mathrm{C}$ until analysis. Flavonoids in the plasma collected were extracted according to a previously described method [20]. Briefly, $150 \mu \mathrm{L}$ plasma was incubated with $300 \mathrm{U}$ of $\beta$-glucuronidase from Helix pomatia in $200 \mu \mathrm{L} 0.1 \mathrm{M}$ sodium acetate buffer $(\mathrm{pH} 5.0)$ and $30 \mu \mathrm{L} 50 \mathrm{mM}$ ascorbic acid for $30 \mathrm{~min}$ at $37^{\circ} \mathrm{C}$. Robinetin (final 
concentration $0.5 \mu \mathrm{mol} / \mathrm{L}$ ) was added to the sample as an internal standard. Samples were then mixed in $1 \mathrm{~mL}$ ethyl acetate for 1 min using a vortex mixer. The mixture was then centrifuged at $15000 \times g$ at $4^{\circ} \mathrm{C}$ for $10 \mathrm{~min}$. The supernatant obtained was collected, and the pellet was re-extracted three times using $1 \mathrm{~mL}$ of ethyl acetate. The ethyl acetate supernatants were combined and reduced to dryness in vacuo. The dried sample was dissolved in $200 \mu \mathrm{L}$ 0.5\% formic acid in methanol before centrifugation at $15000 \times g$ at $4^{\circ} \mathrm{C}$ for $10 \mathrm{~min}$. Next, the sample was analyzed for quercetin, kaempferol, apigenin, luteolin, naringenin, daidzein, genistein, and robinetin using a $\mathrm{Q}$ Exactive LC-MS (Thermo Fisher Scientific, Waltham, MA, USA). The mass spectrometer was operated in the negative-ion electrospray ionization mode with targeted selected-ion monitoring (SIM) mode for all samples. The aforementioned flavonoids were determined using ultra-performance liquid chromatography (UPLC) (Accela; Thermo Fisher Scientific) with an ACQUITY UPLC BEH C18 column (particle size, $1.7 \mu \mathrm{m}$; dimensions, $2.1 \times 100 \mathrm{~mm}$; Waters, MA, USA). The detection limits for these flavonoids were all $0.1 \mu \mathrm{mol} / \mathrm{L}$. A gradient program using solvent $A(0.1 \%$ formic acid $)$ and solvent $B$ (acetonitrile) was used at a flow rate of $0.4 \mathrm{~mL} / \mathrm{min}$. The gradient program was as follows: $0-1 \mathrm{~min}$, hold $2 \% \mathrm{~B}$; 1-2 min, linear gradient to $23 \% \mathrm{~B} ; 2-12 \mathrm{~min}$, hold $23 \%$ B; $12-18 \mathrm{~min}$, linear gradient to $100 \% \mathrm{~B} ; 18-21 \mathrm{~min}$, hold $100 \% \mathrm{~B} ; 21-22 \mathrm{~min}$, linear gradient to $2 \% \mathrm{~B}$; and 22-25 min, hold 2\% B.

Extraction of urine and LC/MS analysis: Flavonoids in the collected urine were extracted according to a previously described method $[20,27]$. Briefly, $5 \mathrm{~mL}$ of urine was incubated with $100 \mathrm{U}$ of $\beta$-glucuronidase from Helix pomatia in $500 \mu \mathrm{L}$ of $0.1 \mathrm{M}$ sodium acetate buffer (pH 5.0) and $1 \mathrm{~mL}$ of $50 \mathrm{mM}$ ascorbic acid at $37^{\circ} \mathrm{C}$ for $30 \mathrm{~min}$. Flavone (final concentration $0.5 \mu \mathrm{mol} / \mathrm{L}$ ) was added to the sample as an internal standard. The solution was applied to a Sep-Pak C18 cartridge (Waters, Milford, MA, USA), which had been pretreated by passage with methanol. The cartridge was washed with $0.01 \mathrm{M}$ oxalic acid and distilled water, and methanol eluate was obtained. The methanol eluate was dried. The dried sample was dissolved in $200 \mu \mathrm{L}$ of $0.5 \%$ formic acid in methanol, followed by centrifugation at $15000 \times$ $g$ at $4^{\circ} \mathrm{C}$ for $10 \mathrm{~min}$. The supernatant was analyzed using LC-MS, as well as plasma extraction and LC/MS analysis.

RNA extraction and real-time RT-PCR: Total RNA from the blood samples in PAXgene RNA fixation solution was extracted using a RNeasy Kit (Qiagen, Venlo, Netherlands), according to the manufacturer's instructions. Then, cDNA was synthesized from total RNA using the Prime Script RT reagent kit (Takara Bio Inc., Tokyo, Japan). Samples were prepared using Power SYBR Green PCR Master Mix (Life Technologies LTD, Renfrewshire, UK), and real-time PCR was performed using a Thermal Cycler Dice Real Time System (Takara Bio Inc., Tokyo, Japan). Amplification was performed with the following PCR conditions: $95^{\circ} \mathrm{C}$ for $30 \mathrm{~s}, 60$ cycles of $95^{\circ} \mathrm{C}$ for $5 \mathrm{~s}$ and $60^{\circ} \mathrm{C}$ for $30 \mathrm{~s}$, and $95^{\circ} \mathrm{C}$ for 15 sec, $60^{\circ} \mathrm{C}$ for $30 \mathrm{~s}$ and $95^{\circ} \mathrm{C}$ for $15 \mathrm{~min}$. Gene expression was normalized to the endogenous control gene, hypoxanthine-guanine phosphoribosyl transferase (HPRT). The PCR primer sequences are listed in Table 4. PCR primers were purchased from Rikaken Co., Ltd. (Aichi, Japan). The cycle threshold (CT) of each gene detected by real-time RT-PCR was calculated as a relative value using the delta-delta CT method [28]. 
Table 4. Sequences of oligonucleotide primers used for real-time RT-PCR

\begin{tabular}{|c|c|c|}
\hline Gene & Direction & Primer Sequence ( $5^{\prime}$ to $3^{\prime}$ ) \\
\hline \multirow{2}{*}{$\begin{array}{l}\text { Hypoxanthine - guanine } \\
\text { phosphoribosyl transferase (HPRT) }\end{array}$} & Forward & GATTTGGAAAGGGTGTTTATTCCTC \\
\hline & Reverse & TCССАТТСТСТTСАТСАСАТСТС \\
\hline \multirow[t]{2}{*}{ Interleukin 1 beta (IL-1 $\beta$ ) } & Forward & CTGTCCTGCGTGTTGAAAGA \\
\hline & Reverse & TGGGTAATTTTTGGGATCTACA \\
\hline \multirow[t]{2}{*}{ Interleukin 6 (IL-6) } & Forward & GAAAGTGGCTATGCAGTTTGAA \\
\hline & Reverse & AGCCTACACTTTCCAAGAAATGA \\
\hline \multirow[t]{2}{*}{ Interleukin 18 (IL-18) } & Forward & CAACAAACTATTTGTCGCAGGA \\
\hline & Reverse & TGCCACAAAGTTGATGCAAT \\
\hline \multirow[t]{2}{*}{ Tumor necrosis factor (TNF- $\alpha$ ) } & Forward & CAGCСTСTTСТССTTCСTGAT \\
\hline & Reverse & GCCAGAGGGCTGATTAGAGA \\
\hline
\end{tabular}

PCR primers were purchased from Rikaken Co., Ltd. (Aichi, Japan).

Statistical analysis: Data were analyzed using the Statistical Analysis System software (SPSS, version 22.0, Chicago, IL, USA). All values are presented as mean \pm SD. A post-hoc Tukey's test was used to analyze the data obtained. Results were considered significant at $p<0.05$.

\section{RESULTS}

\section{Estimates of daily nutrient intake by the participants}

The seven participants are indicated as No. 1 to No. 7 . The average estimated daily nutrient intake of the participants was $2,658 \pm 709 \mathrm{kcal}$ for energy, $87.7 \pm 24.9$ $\mathrm{g}$ for protein, $83.7 \pm 26.9 \mathrm{~g}$ for lipids, and $371 \pm 117 \mathrm{~g}$ for carbohydrates (Table 5). Comparing the estimated energy intake with the DRIs for the Japanese population (2015), the values of Nos. 1 to 4 in the normal group were almost the same at 2,110-2,331 kcal, but that of No. 5 in the obesity group was 4,279 kcal, No. 6 also tended to be slightly high at 2,728 kcal, and No. 7 as well at 2,804 kcal. In particular, No. 5 showed a high intake of other nutrients because of the high intake of food.

\section{Analysis of flavonoid-rich and low-flavonoid meals}

The flavonoid content of the flavonoid-rich meals is shown in Table 6. The average flavonoid content per meal used in the intervention study was $46.9 \pm 8.1$ $\mathrm{mg} / \mathrm{meal}$. This flavonoid content was approximately two times higher than the daily flavonoid intake of 21.3 $\mathrm{mg} / \mathrm{meal}$ in a Japanese population in a previous study [22]. Among all flavonoids investigated in this study, genistein had the highest concentration (17.6 \pm 4.3 $\mathrm{mg} / \mathrm{meal})$, followed by daidzein $(14.7 \pm 5.3 \mathrm{mg} / \mathrm{meal})$, quercetin (11.2 $\pm 2.9 \mathrm{mg} / \mathrm{meal})$, and kaempferol (1.8 \pm $1.3 \mathrm{mg} / \mathrm{meal}$ ). The other flavonoids (apigenin, luteolin, naringenin) were below the detection limit under these experimental conditions (data not shown).

The flavonoid content of the low-flavonoid meals was below the detection limit (Table 6) . 
Table 5. Estimated daily intake of nutrients by the subjects $(n=7)$

\begin{tabular}{|c|c|c|c|c|c|c|c|c|c|c|c|c|c|}
\hline $\begin{array}{l}\text { Subject } \\
\text { number }\end{array}$ & Energy & Protein & Fat & $\begin{array}{l}\text { Carbo- } \\
\text { hydrate }\end{array}$ & Calcium & Iron & $\begin{array}{c}\text { Retinol } \\
\text { equivalent }\end{array}$ & $\begin{array}{c}\text { Vitamin } \\
\text { B1 }\end{array}$ & $\begin{array}{l}\text { Vitamin } \\
\text { B2 }\end{array}$ & $\begin{array}{c}\text { Vitamin } \\
\text { C }\end{array}$ & $\begin{array}{c}\text { Vitamin } \\
\text { E }\end{array}$ & $\begin{array}{c}\text { Total } \\
\text { dietary } \\
\text { fiber }\end{array}$ & $\begin{array}{c}\text { Salt } \\
\text { equivalents }\end{array}$ \\
\hline & kcal & g & g & g & $\mathrm{mg}$ & $\mathrm{mg}$ & $\mu \mathrm{g}$ & $\mathrm{mg}$ & $\mathrm{mg}$ & $\mathrm{mg}$ & $\mathrm{mg}$ & g & g \\
\hline 1 & 2331 & 60.9 & 58.1 & 364 & 409 & 5.8 & 379 & 0.73 & 0.86 & 54 & 5.8 & 11.8 & 7.4 \\
\hline 2 & 2191 & 68.0 & 63.2 & 324 & 437 & 6.0 & 494 & 0.92 & 0.93 & 70 & 5.7 & 11.1 & 7.6 \\
\hline 3 & 2165 & 74.4 & 62.7 & 303 & 427 & 7.0 & 506 & 0.89 & 0.92 & 52 & 6.3 & 9.9 & 8.5 \\
\hline 4 & 2110 & 82.0 & 83.3 & 245 & 753 & 7.1 & 673 & 1.21 & 1.50 & 101 & 6.4 & 12.0 & 13.2 \\
\hline 5 & 4279 & 128.8 & 135.4 & 629 & 601 & 12.2 & 800 & 1.82 & 1.76 & 185 & 10.8 & 25.3 & 21.5 \\
\hline 6 & 2728 & 76.9 & 72.1 & 425 & 410 & 7.7 & 557 & 1.10 & 0.93 & 85 & 7.5 & 14.8 & 6.2 \\
\hline 7 & 2804 & 122.9 & 110.8 & 312 & 1184 & 12.9 & 1071 & 1.54 & 2.26 & 193 & 9.5 & 17.3 & 8.8 \\
\hline Mean \pm & $2658 \pm$ & $87.7 \pm$ & $83.7 \pm$ & $371 \pm$ & $603 \pm$ & $8.4 \pm$ & $640 \pm$ & $1.17 \pm$ & $1.31 \pm$ & $105 \pm$ & $7.4 \pm$ & $14.6 \pm$ & $10.5 \pm$ \\
\hline SD & 709 & 24.9 & 26.9 & 117 & 265 & 2.7 & 216 & 0.36 & 0.50 & 55 & 1.8 & 4.9 & 4.9 \\
\hline
\end{tabular}

The subjects are indicated by No.1 to No.7. No.1 to No.4 with BMI $<25 \mathrm{~kg} / \mathrm{m}^{2}$ comprised the normal group, and No.5 to No.7 with $\mathrm{BMI} \geq 25 \mathrm{~kg} / \mathrm{m}^{2}$ comprised the obesity group.

Table 6. Total flavonoid content of nine meals

\begin{tabular}{|c|c|c|c|c|c|c|}
\hline \multicolumn{2}{|c|}{ Menu number } & \multicolumn{5}{|c|}{ Quantity of flavonoids (mg / meal) } \\
\hline & & Quercetin & Kaempferol & Daidzein & Genistein & Total \\
\hline \multirow[t]{10}{*}{ Rich meals } & 1 & $10.5 \pm 0.1$ & $2.7 \pm 0.1$ & $13.7 \pm 0.4$ & $19.6 \pm 0.4$ & $46.5 \pm 0.4$ \\
\hline & 2 & $15.0 \pm 0.6$ & ud & $24.7 \pm 0.5$ & $25.5 \pm 0.1$ & $65.2 \pm 0.6$ \\
\hline & 3 & $6.5 \pm 0.1$ & $2.7 \pm 0.1$ & $15.9 \pm 0.3$ & $16.9 \pm 0.1$ & $42.0 \pm 0.5$ \\
\hline & 4 & $11.5 \pm 0.1$ & $2.7 \pm 0.1$ & $15.3 \pm 0.3$ & $17.7 \pm 0.1$ & $47.2 \pm 0.3$ \\
\hline & 5 & $11.7 \pm 0.1$ & ud & $13.8 \pm 0.3$ & $17.6 \pm 0.1$ & $43.1 \pm 0.4$ \\
\hline & 6 & $11.7 \pm 0.1$ & $2.7 \pm 0.1$ & $11.8 \pm 0.3$ & $15.0 \pm 0.1$ & $41.2 \pm 0.3$ \\
\hline & 7 & $15.9 \pm 0.1$ & $2.7 \pm 0.1$ & $14.0 \pm 0.4$ & $14.9 \pm 0.1$ & $47.6 \pm 0.3$ \\
\hline & 8 & $6.3 \pm 0.1$ & ud & $15.9 \pm 0.3$ & $16.9 \pm 0.1$ & $38.8 \pm 0.5$ \\
\hline & 9 & $10.9 \pm 0.1$ & $2.7 \pm 0.1$ & $9.4 \pm 0.4$ & $12.7 \pm 0.1$ & $35.7 \pm 0.5$ \\
\hline & Mean \pm SD & $11.2 \pm 2.9$ & $1.8 \pm 1.3$ & $14.7 \pm 5.3$ & $17.6 \pm 4.3$ & $46.9 \pm 8.1$ \\
\hline Low meals & 1 to 9 & ud & ud & ud & ud & ud \\
\hline
\end{tabular}

ud: under the detection limit 
Apigenin, luteolin, naringenin contents were below the detection limit in these experimental conditions.

The average flavonoid content in the flavonoid-rich meals was $46.9 \pm 8.1 \mathrm{mg} / \mathrm{meal}$, which was more than twice higher than that in the study by Arai et al. [22].

Flavonoid concentration in plasma: The flavonoid concentrations in plasma after ingesting flavonoid-rich and low-flavonoid meals are shown in Fig 2 and Fig 3, respectively. In the normal group of the flavonoid-rich group, quercetin showed a significant increased from $4.1 \pm 0.9$ to $7.1 \pm 1.6 \mu \mathrm{mol} / \mathrm{L}$, and kaempferol, daidzein, and genistein also showed a significant increase from $2.9 \pm 0.7$ to $5.2 \pm 1.2 \mu \mathrm{mol} / \mathrm{L}$, under detected to $0.5 \pm$ $0.3 \mu \mathrm{mol} / \mathrm{L}$, and $0.1 \pm 0.1$ to $1.6 \pm 0.8 \mu \mathrm{mol} / \mathrm{L}$, respectively (Fig 2). Similarly, in the obesity group, quercetin was significantly increased from $3.7 \pm 1.4$ to $6.4 \pm 0.9 \mu \mathrm{mol} / \mathrm{L}$, and kaempferol, daidzein, and genistein also showed a significant increase from $2.9 \pm$ 1.1 to $4.9 \pm 0.7 \mu \mathrm{mol} / \mathrm{L}$, under detected to $0.2 \pm 0.7$ $\mu \mathrm{mol} / \mathrm{L}$, under detected to $1.2 \pm 0.3 \mu \mathrm{mol} / \mathrm{L}$ respectively (Fig 2). Apigenin, luteolin, and naringenin, which were not detected in flavonoid-rich meals, were below the detection limit even in plasma samples of either group of the flavonoid-rich group (data not shown).

There were no significant changes in the plasma concentrations of quercetin, kaempferol, daidzein, and genistein in either the normal or obesity groups of the low-flavonoid group (Fig 3). In addition, apigenin, luteolin, and naringenin were below the detection limit in the low-flavonoid group (data not shown).

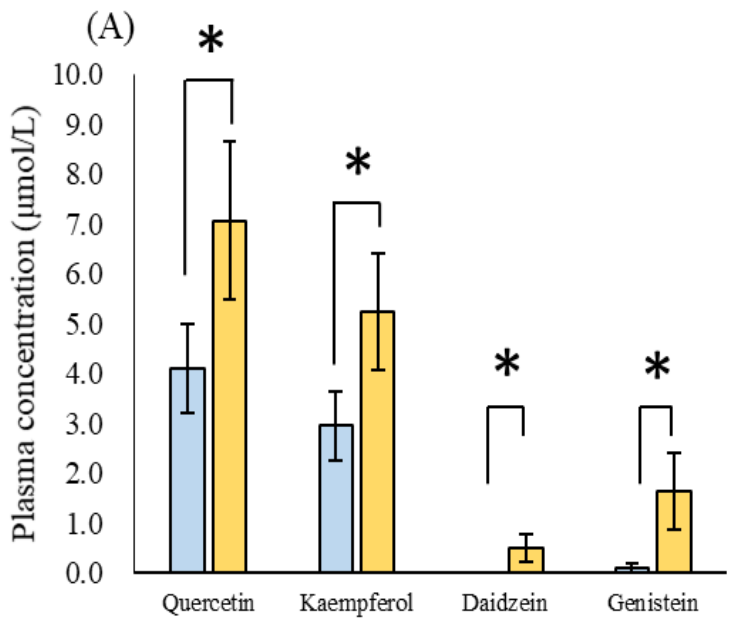

(B)

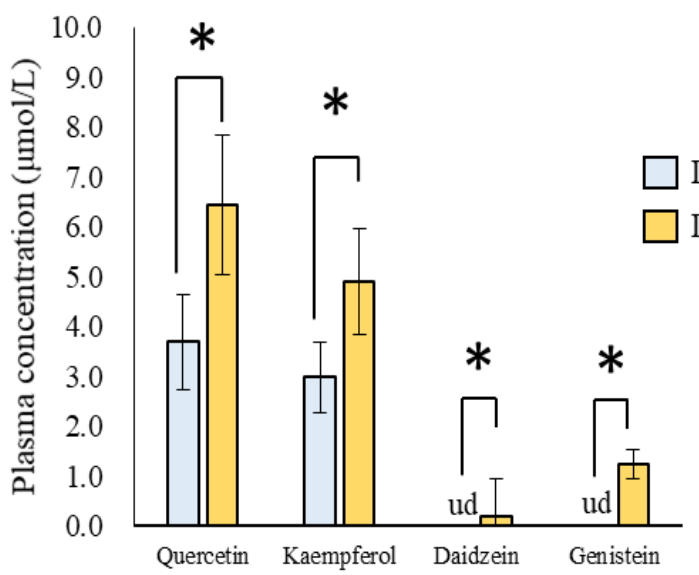

Figure 2. Concentrations of quercetin, kaempferol, daidzein, genistein in plasma of subjects on day 0 (white bar) and day 7 (black bar) after flavonoid-rich meal intake.

(A) is a normal group with a BMI $<25 \mathrm{~kg} / \mathrm{m}^{2}(\mathrm{n}=4)$, and $(B)$ is an obesity group with a BMI $\geq 25 \mathrm{~kg} / \mathrm{m}^{2}(\mathrm{n}=3)$. The values are means \pm standard deviation. The asterisk indicates a significant difference vs day $0, p<0.05$.

ud: under the detection limit 
(A)

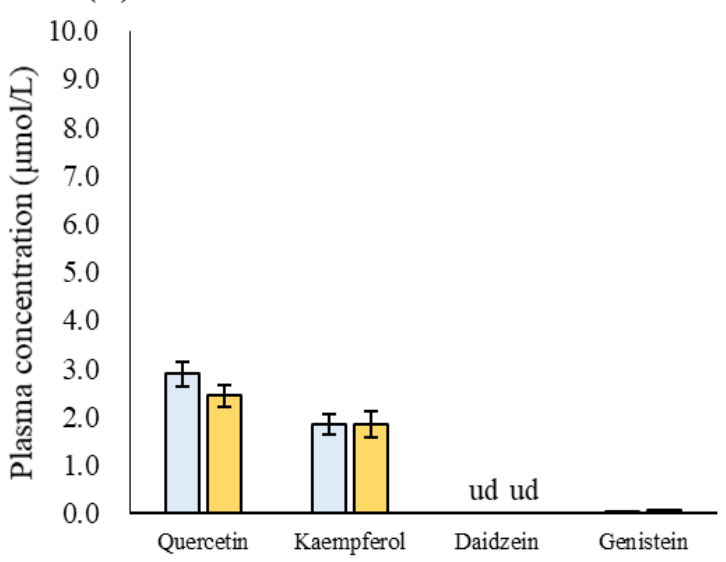

(B)

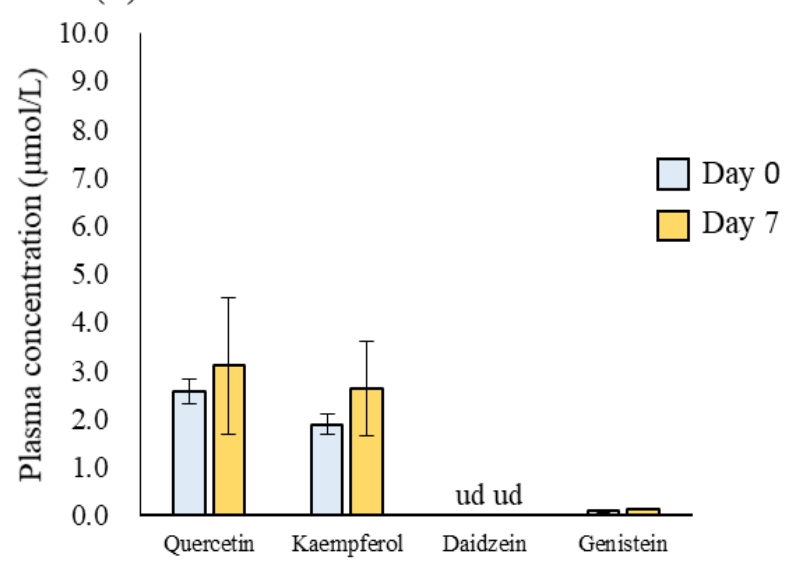

Figure 3. Concentrations of quercetin, kaempferol, daidzein, genistein in plasma of subjects on 0 day (white bar) and 7 day (black bar) after low-flavonoid meal intake. (A) is a normal group with a BMI $<25 \mathrm{~kg} / \mathrm{m}^{2}(\mathrm{n}=4)$, and $(B)$ is an obesity group with a BMI $\geq 25 \mathrm{~kg} / \mathrm{m}^{2}(\mathrm{n}=3)$. The values are means \pm standard deviation. The asterisk indicates a significant difference vs day $0, p<0.05$.

ud: under the detection limit

Urinary excretion of flavonoids: Flavonoid excretion in urine is shown in Fig 4 and Fig 5 . Urinary flavonoid excretion in the normal group in flavonoid-rich group were significantly increased from $0.2 \pm 0.1$ to $5.8 \pm 4.1$ $\mathrm{mM} / \mathrm{M}$ of Cre for quercetin. There was also a significantly increase in kaempferol, daidzein, and genistein from $0.4 \pm 0.2$ to $3.3 \pm 2.6 \mathrm{mM} / \mathrm{M}$ of Cre, under detected to $43.5 \pm 26.8 \mathrm{mM} / \mathrm{M}$ of Cre, $0.3 \pm 0.2$ to $76.2 \pm 50.2 \mathrm{mM} / \mathrm{M}$ of Cre, respectively (Fig 4). Similarly, in the obesity group were significantly increased from $0.1 \pm 0.1$ to $4.4 \pm 4.6 \mathrm{mM} / \mathrm{M}$ of Cre for quercetin. There was also a significantly increase in kaempferol, daidzein, and genistein from $0.3 \pm 0.2$ to 2.2 $\pm 2.0 \mathrm{mM} / \mathrm{M}$ of Cre, $0.4 \pm 0.6$ to $32.6 \pm 32.0 \mathrm{mM} / \mathrm{M}$ of Cre, $2.5 \pm 2.3$ to $57.0 \pm 53.5 \mathrm{mM} / \mathrm{M}$ of Cre, respectively (Fig 4).

On the other hand, in the low-flavonoid group, no significant change was observed in either group, unlike in the flavonoid-rich group (Fig 5). In addition, apigenin, luteolin, and naringenin contents were below the detection limit in the flavonoid-rich group and lowflavonoid group, as in the plasma (data not shown).
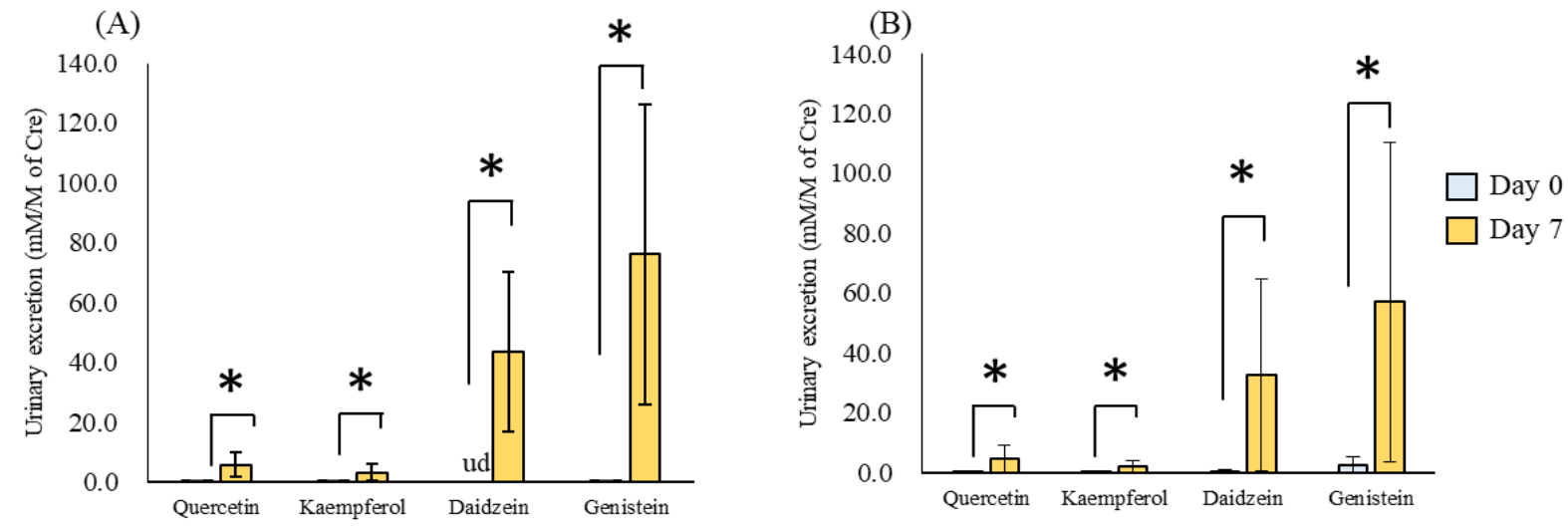

Figure 4. Excretions of quercetin, kaempferol, daidzein, genistein in urinary of subjects on day 0 (white bar) and day 7 (black bar) after flavonoid-rich meal intake. (A) is a normal group with a BMI $<25 \mathrm{~kg} / \mathrm{m}^{2}(\mathrm{n}=4)$, and (B) is an obesity group with a $B M I \geq 25 \mathrm{~kg} / \mathrm{m}^{2}(\mathrm{n}=3)$. The values are means \pm standard deviation. The asterisk indicates a significant difference vs day $0, p$ $<0.05$.

ud: under the detection limit 
(A)

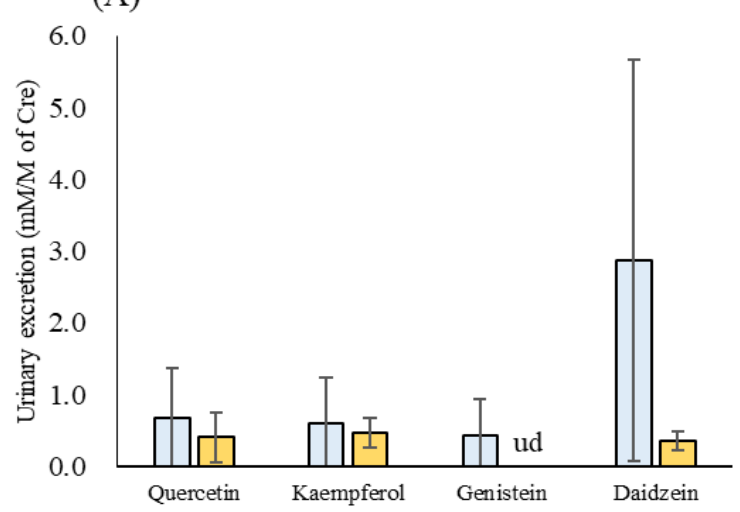

(B)

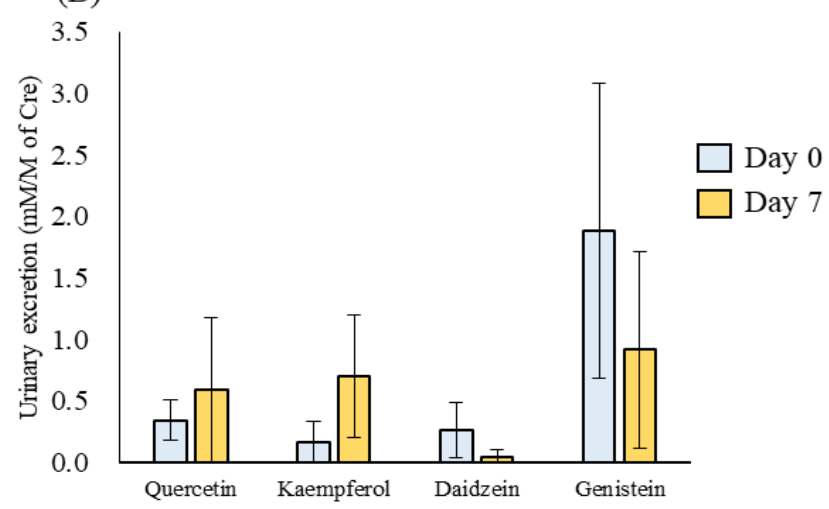

Figure 5. Excretion of quercetin, kaempferol, daidzein, genistein in urinary of subjects on day 0 (white bar) and day 7 (black bar) after low-flavonoid meal intake. (A) is a normal group with a BMI $<25 \mathrm{~kg} / \mathrm{m}^{2}(\mathrm{n}=4)$, and (B) is an obesity group with a $\mathrm{BMI} \geq 25 \mathrm{~kg} / \mathrm{m}^{2}(\mathrm{n}=3)$. The values are means \pm standard deviation. The asterisk indicates a significant difference vs day $0, p$ $<0.05$.

ud: under the detection limit

Measurement of gene expression in the whole blood

cells: Gene expression levels in whole blood cells were measured using RT-PCR. The change in gene expression levels due to the intervention was calculated using a relative quantification method (Fig 6 and Fig 7). The measured genes were inflammatory markers IL-1 $\beta$, interleukin 6 (IL-6), interleukin 18 (IL-18), and TNF- $\alpha$. The hypoxanthine-guanine phosphoribosyl transferase (HPRT) gene was used as an endogenous control.
The participants that had flavonoid-rich meals in obesity group had significantly reduced gene expression levels of all measured inflammatory cytokines (Fig 6-B). Conversely, no significant difference was observed in the gene expression levels of the inflammatory cytokines in the participants of the obesity group that had low-flavonoid meals (Fig 7-B).
(A)

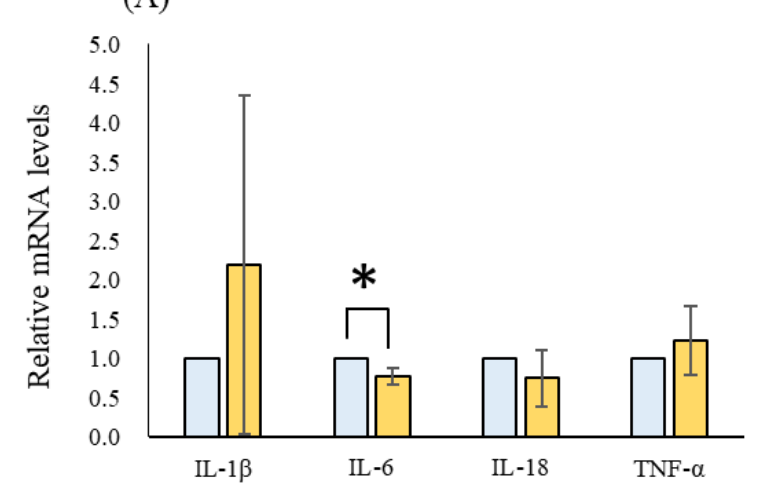

(B)

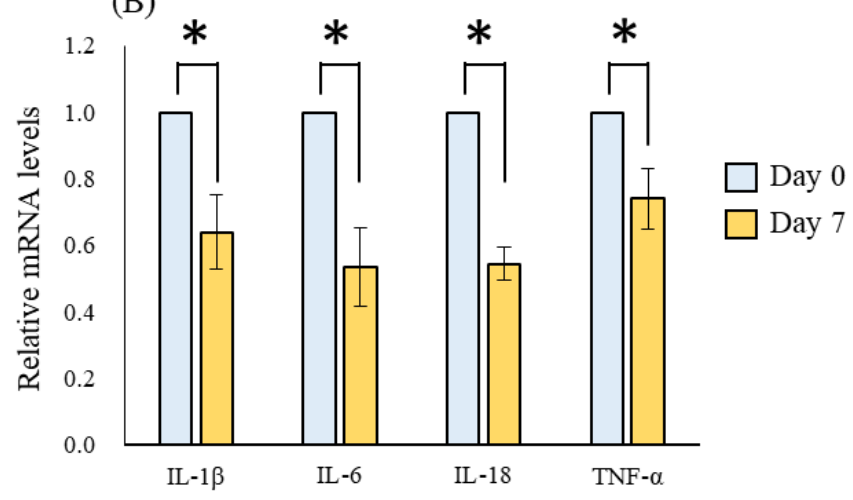

Figure 6. Relative mRNA expression levels of inflammatory cytokines in whole blood cells of subjects on day 0 (white bar) and day 7 (black bar) after flavonoid-rich meal intake. The expression of inflammatory cytokine is shown as a relative value with 0 day as 1 . (A) is a normal group with a $B M I<25 \mathrm{~kg} / \mathrm{m}^{2}(n=4)$, and (B) is an obesity group with a $B M I \geq 25 \mathrm{~kg} / \mathrm{m}^{2}(n=3)$. The values are means \pm standard deviation. The asterisk indicates a significant difference vs day $0, p<0.05$. 

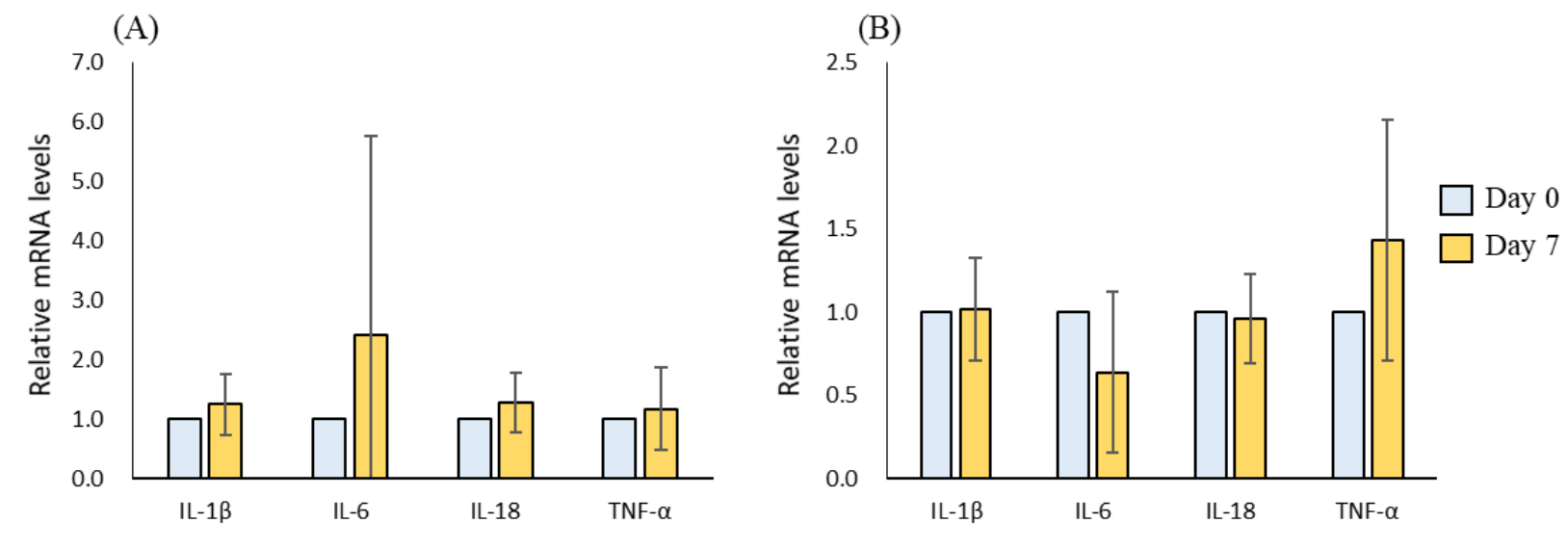

Figure 7. Relative mRNA expression levels of inflammatory cytokines in whole blood cells of subjects on day 0 (white bar) and day 7 (black bar) after low-flavonoid meal intake. The expression of inflammatory cytokine is shown as a relative value with 0 day as 1 . (A) is a normal group with a $B M I<25 \mathrm{~kg} / \mathrm{m}^{2}(\mathrm{n}=4)$, and $(B)$ is an obesity group with a $B M I \geq 25 \mathrm{~kg} / \mathrm{m}^{2}(n=3)$. The values are means \pm standard deviation.

\section{DISCUSSION}

Almost all epidemiological studies that evaluated the preventive effect of flavonoid intake on disease were performed by means of a questionnaire about intake of flavonoid-containing foods and calculation of flavonoid content of the foods [2,21,22]. For example, Arai et al. [22] reported that the average of flavonoid intake in 117 healthy Japanese people was $21.3 \mathrm{mg} / \mathrm{meal}$. In this study, we did human intervention investigation using test meals with a specific amount of flavonoids. The average flavonoid content in the flavonoid-rich meals was $46.9 \pm 8.1 \mathrm{mg} / \mathrm{meal}$ (Table 6), which was more than twice higher than that in the study by Arai et al. [22]. To the best of our knowledge, this study is the first human intervention study that examined the gene expression levels of inflammatory cytokines using an actual diet, flavonoid rich and low meals determined flavonoid contents by HPLC analysis. In addition, an actual diet took into account nutrient levels. We considered this study with 7 subjects, even though a small number, has significance.
In the obesity group (BMI $\left.\geq 25 \mathrm{~kg} / \mathrm{m}^{2}\right)$, the expression levels of all four inflammatory cytokines (IL$1 \beta, I L-6, I L-18$, and TNF- $\alpha$ ) measured decreased after the intervention with flavonoid-rich meals (Fig 6 and 7). However, in the normal group (BMI $\left.<25 \mathrm{~kg} / \mathrm{m}^{2}\right)$ there was almost no decrease in inflammatory cytokine gene expression even though they had flavonoid-rich meals. In obese individuals, it has been shown that the amount of oxidants increases due to oxidation of adipose tissue [29], chronic inflammation has been reported to occur [16], and it is possible that the expression levels of inflammatory cytokines may increase. Therefore, it was considered that the anti-inflammatory effect of flavonoids was likely to be more evident in the body of the participants in the obesity group. In turn, it has been reported that chronic inflammation does not occur in healthy subjects [16]. Zahedi et al. [16] and Boots et al. [17]. also found that oral administration of quercetin reduces inflammatory cytokine levels such as TNF- $\alpha$ in patients with diabetes and patients with sarcoidosis and chronic inflammation in vivo. 
Conversely, Egert et al [30]. reported that oral administration of quercetin did not change the concentration of TNF- $\alpha$ in blood in healthy subjects. We thus concluded that chronic inflammation occurs in obese participant and that antioxidant and antiinflammatory actions due to flavonoid intake are likely to be effective.

It has been reported that chronic inflammatory responses in vivo, such as in obese persons, may result in the release of $\beta$-glucuronidase from inflammatory cells, leading to flavonoids deconjugation and an antiinflammatory effect. Shimoi et al reported that plasma $\beta$-glucuronidase activity is high in hemodialysis patients with an induced inflammatory response [31]. In addition, Kawai et al demonstrated that activation of macrophages during the inflammatory response in human atherosclerotic foci results in the release of $\beta$ glucuronidase, which leads to decondensation and metabolic conversion of quercetin-3-O-glucuronide (Q3G) to aglycone. Thus, it has been suggested that at sites of inflammation, glucuronides may be converted into a highly active aglycone, which may have antiinflammatory effects [32]. Although the antiinflammatory action mechanism of flavonoids in obese individuals are still unclear, it is possible that the flavonoid intake may have been more effective for them because of the responses described above.

In this dietary intervention study, it was necessary to consider and investigate the effect of the daily nutritional intake of the participants. Therefore, we investigated the daily nutrients intake of the participants by asking them to answer the frequency of food intake in the past a month using FFQg [26]. It became clear that No. 5 to No. 7 had high energy intake and nutritional intake was not well balanced (Table 5). In the participants of No. 1 to No. 4, retinol, vitamin B2, and vitamin $C$, which have antioxidant activity, were lower than the DRIs for the Japanese population (2015) [23]. Conversely, the low-flavonoid meals used in this study, as the flavonoid-rich meals, were designed taking into consideration of energy and nutrients based on DRIs for the Japanese (2015) [23]. That is, it was considered that the meal with improved balanced nutrition and energy was provided during this study, compared with the meal that the participants took daily. Therefore, we speculated that intervention with lowflavonoid meals also improved nutritional status and reduced gene expression of some inflammatory cytokines. However, the effect of the correction of nutritional status was also considered in the intervention with the flavonoid-rich meal, but in three obese participants, more inflammatory markers were reduced in the flavonoid-rich intervention (flavonoidrich group) than in the low-flavonoid intervention (lowflavonoid group). This suggested that the intake of more flavonoids may have an anti-inflammatory effect.

It was found that continuous intake of flavonoidrich meals for one week significantly increased plasma concentration of flavonoids after the intervention compared to before the intervention (Fig 2). Egert et al [30] conducted a study in which Germans (BMI < 25 $\mathrm{kg} / \mathrm{m}^{2}$ ) were fed 50,100 , and $150 \mathrm{mg}$ of quercetin supplement for 14 days. As a result, they reported that the plasma concentration of quercetin significantly increased after intervention. Conversely, Young et al. [33] conducted a study in which Danish people (BMI < $25 \mathrm{~kg} / \mathrm{m}^{2}$ ) ingested fruit juice mixes with apples and grapes at $1500 \mathrm{~mL} /$ day (quercetin amount: $9.6 \mathrm{mg} /$ day) for one week. At this time, they reported that there was no change in the plasma concentration of quercetin before and after the intervention. These reports suggest that it is necessary to ingest a certain amount 
or more of flavonoids in order for the flavonoids to be absorbed into the body. In addition, in the intervention study using fruit juice [33], 24-hour urine collection was also performed, showing that the intervention significantly increased urinary flavonoid excretion. Therefore, urinary flavonoid excretion may be a more sensitive biomarker of quercetin intake than plasma concentration of flavonoids. In general, flavonoids have been reported to peak in plasma concentrations one to four hours after meal intake [34]. In addition, in our previous study, we found that the peak of plasma concentration of flavonoids is delayed when flavonoids are ingested in a complex of various components such as meals [20]. Therefore, it can be inferred that it is difficult for blood sampling to overlap with the peak flavonoid concentration in plasma. However, it is considered that 24-hour urine collection can be an accurate biomarker for flavonoid intake because it is not necessary to take into account the peak of flavonoid concentration as described for plasma. As shown in Fig 2 to 5, in this study, urinary flavonoids also showed a sharp increase in the excretion due to the intervention compared to plasma. This suggested that urinary flavonoid excretion using 24-hour urine collection could be a more sensitive biomarker of flavonoid intake than plasma concentration.

In this study, subjects with a BMI $\geq 25 \mathrm{~kg} / \mathrm{m}^{2}$ were considered to be in a chronic inflammatory state, and the anti-inflammatory effect of flavonoid intake from meals was shown. Although the number of subjects was as small as seven, the results of this study further proved the usefulness of flavonoids for human health.

\section{CONCLUSION}

In this study, in obese participants with a BMI $\geq 25$ $\mathrm{kg} / \mathrm{m}^{2}$, it was possible that ingestion of an average of
$46.9 \pm 8.1 \mathrm{mg} / \mathrm{meal}$ of flavonoids from meals for one week significantly reduced gene expression of inflammatory cytokines and could alleviate inflammation. In addition, future intervention studies with an increased number of subjects showing chronic inflammation is expected to demonstrate antiinflammatory effect of flavonoid-rich meals considering energy and nutrients.

List of abbreviations used: ROS, reactive oxygen species; IL-1 $\beta$, interleukin 1 beta; TNF- $\alpha$, tumor necrosis factor- $\alpha$; DRIs, dietary reference intakes; HPLC, highperformance liquid chromatography; LC-MS, liquid chromatography-tandem mass spectrometry; BMI, body mass index; FFQg, Food Frequency Questionnaire Based on Food Groups; TFA, trifluoroacetic acid; ESI, electrospray ionization; SIM, selected-ion monitoring; UPLC, ultra-performance liquid chromatography; HPRT, hypoxanthine-guanine phosphoribosyl transferase; CT, cycle threshold; IL-6, interleukin 6; IL-18 interleukin 18.

Competing interests: The authors declare no competing financial interests.

Authors' Contributions: Mr. Mannen and Dr. Yasuda conducted the study and performed the tests. Dr. Ichikawa and Dr. Shimoi contributed to the analysis and interpretation of data and assisted in the preparation of the manuscript.

All authors contributed to data collection and interpretation, and critically reviewed the manuscript.

Acknowledgments and Funding: The authors would like to thank Dr. Takahiro Hosoya (Toyo University), Dr. Yuichi Miyake (University of Shizuoka), and Dr. Shigenori Kumazawa (University of Shizuoka) for their technical 
assistance. This work was supported by JSPS KAKENHI, Grant Number JP25350098 and JP16K00818.

\section{REFERENCES}

1. Williams CA, Grayer RJ: Anthocyanins and other flavonoids. Nat Prod Rep 2004, 21: 539-573.

2. Hertog MG, Feskens EJ, Hollman PC, Katan MB, Kromhout D: Dietary antioxidant flavonoids and risk of coronary heart disease: the Zutphen Elderly Study. Lancet 1993, 342: 1007-1011.

3. Wang $X$, Ouyang YY, Liu J, Zhao G: Flavonoid intake and risk of CVD: a systematic review and meta-analysis of prospective cohort studies. Br J Nutr 2014, 111: 1-11.

4. Kim $Y$, Je $Y$ : Flavonoid intake and mortality from cardiovascular disease and all causes: A meta-analysis of prospective cohort studies. Clinical nutrition ESPEN 2017, 20: 68-77.

5. Lobo V, Patil A, Phatak A, Chandra N: Free radicals, antioxidants and functional foods: Impact on human health. Pharmacogn Rev 2010, 4: 118-126.

6. Sakakibara $\mathrm{H}$, Ashida $\mathrm{H}$, Kanazawa $\mathrm{K}$ : A novel method using 8-hydroperoxy-2'-deoxyguanosine formation for evaluating antioxidative potency. Free Radical Res 2007, 36: 307-316.

7. Maleki SJ, Crespo JF, Cabanillas B: Anti-inflammatory effects of flavonoids. Food chem 2019, 299: 125124.

8. Jennings A, Welch AA, Spector T, Macgregor A, Cassidy A: Intakes of anthocyanins and flavones are associated with biomarkers of insulin resistance and inflammation in women. J nitr 2014, 144: 202-208.

9. Dana M Niedowicz, David Daleke: The role of oxidative stress in diabetic complications. Cell Biochem Biophys 2005, 43: 289-330.

10. M E Ginn-Pease, R L Whisler: Redox signals and NF-KappaB activation in T cell. Free Radic Biol Med 1998, 25: 346-361.

11. Haddad JJ: Redox regulation of pro-inflammatory cytokines and IkappaB-alpha/NF-kappaB nuclear translocation and activation. Biochem Biophys Res Commun 2002, 30: 847-856.

12. Yokoyama A, Sakakibara H, Crozier A, Kawai Y, Matsui A, Terao J, Kumazawa S, Shimoi K: Quercetin metabolites and protection against peroxynitrite-induced oxidative hepatic injury in rats. Free Radic Res 2009, 43: 913-921.

13. Sánchez $M$, Romero $M$, Gómez-Guzmán $M$, Tamargo J, Pérez-Vizcaino F, Duarte J: Cardiovascular Effects of
Flavonoids. Curr Med Chem 2019, 26: 6991-7034.

14. Azuma K, Minami Y, Ippoushi K, Terao J: Lowering effects of onion intake on oxidative stress biomarkers in streptozotocin-induced diabetic rats. J Clin Biochem Nutr 2007, 40: 131-140.

15. Freeland-Graves $\mathrm{JH}$, Nizke $\mathrm{S}$, Academy of Nutrition and Dietetics: Academy of Nutrition and Dietetics. Position of the academy of nutrition and dietetics: total diet approach to slim eating. J Acad Nutr Diet 2013, 113: 307317.

16. Zahedi M, Ghiasvand R, Feizi A, Asgari G, Darvish L: Does Quercetin Improve Cardiovascular Risk factors and Inflammatory Biomarkers in Women with Type 2 Diabetes: A Double-blind Randomized Controlled Clinical Trial. Int J Prev Med 2013, 4: 777-785.

17. Boots AW, Drent $M$, de Boer VC, Bast A, Haenen GR: Quercetin reduces markers of oxidative stress and inflammation in sarcoidosis. Clin Nutr 2011, 30: 506-512.

18. Cristina Z, Lucinda V, Jorge M, Francisco Z, Melchor: Potential therapeutic anti-inflammatory and immunomodulatory effects of dihydroflavones, flavones, and flavonols. Molecules 2020, 25:1017.

19. Huang Y, Cao S, Nagamani M, Anderson K, Grady J, Lu L: Decreased circulating levels of tumor necrosis factor-alpha in postmenopausal women during consumption of soycontaining isoflavones. J Clin Endocrinol Metab 2005, 90:3956-3962.

20. Mannen R, Yasuda T, Sano A, Goda T, Shimoi K, Ichikawa Y: Changes in plasma concentration of flavonoids after ingestion of a flavonoid-rich meal prepared with basic foodstuffs. Funct. Foods Health Dis 2019, 9: 55-575.

21. Knekt $P$, Kumpulzinen $T$, Järvinen $R$, Rissanen $H$, Heliövaara M, Reunanen A, Hakulinen T, Aromaa A: Flavonoid intake and risk of chronic diseases. Am J Clin Nutr 2002, 76: 560568.

22. Arai $Y$, Watanabe S, Kimira M, Shimoi K, Mochizuki R, Kinae $\mathrm{N}$ : Dietary intakes of flavonols, flavones and isoflavones by Japanese women and the inverse correlation between quercetin intake and plasma LDL cholesterol concentration. J Nutr 2002, 130: 2243-2250.

23. Hishida A, Sasaki S: Dietary Reference Intakes for Japanese, 2015. First edition. Edited by Daiichi-syuppan. Tokyo, Japan: 2014;45-300.

24. Kagawa A: Standard tables of food composition in Japan. Seventh edition. Edited by Joshieiyoudaigaku-syuppan. Tokyo, Japan: 2015;1-300 
25. Sakakibara H, Ichikawa $Y$, Tajima S, Makino Y, Wakasugi $Y$, Shimoi K, Kobayashi S, Kumazawa S, Goda T: Practical application of flavonoid-poor meals to the study of the bioavailability of bilberry anthocyanins in human subjects. Biosci Biotechnol Biochem 2014, 78: 1748-1752.

26. Takahashi K, Yoshimura Y, Kaimoto T, Kunii D, Komatsu T,Yamamoto S: Validation of a food frequency questionnaire based on food groups for estimating individual nutrient intake. Journal of Nutrition 2001, 59: 221-231.

27. Murota K, Matsuda N, Kashino Y, Fujikura Y, Nalamura T, Kato Y, Shimizu R, Okuyama S, Tanaka H, Koda T, Seido K, Terao J: Alpha- oligoglucosylation of a sugar moiety enhances the bioavailability of quercetin glucosides in humans. Arch Biochem Biophys 2010, 501: 91-97.

28. Osonoi T, Saito M, Mochizuki K, Fukaya N, Muramatsu T, Inoue S, Fuchigami M, Goda T: alpha-Oligoglucosylation of a sugar moiety enhances the bioavailability of quercetin glucosides in humans. Arch. Biochem. Biophys 2010, 501: 91-97.

29. Furukawa S, Fujita T, Shimabukuro M, Iwaki M, Yamada $Y$, Nakajima Y, Nakayama O, Makishima M, Matsuda M, Shimomura I: Increased oxidative stress in obesity and its impact on metabolic synfrome. J Clin Invest 2004, 114: 1752-1761

30. Egert S, Wolffram S, Bosy-Westphal A, BoeschSaadatmandi C, Wagner AE, Frank J, Rimbach G, Mueller MJ: Daily quercetin supplementation dose-dependently increases plasma quercetin concentrations in healthy humans. J Nutr 2008, 138: 1615-1621.

31. Shimoi K, Saka N, Nozawa R, Sato M, Amano I, Nakayama $\mathrm{T}$, Kinae $\mathrm{N}$ : Deglucuronidation of a flavonoid, luteolin monoglucuronide, during inflammation. Drug Metab Dispos 2001, 29: 1521-1524.

32. Kawai Y, Kawai Y, Nishikawa T, Shiba Y, Saito S, Murota K, Shibata N, Kobayashi M, Kanayama M, Uchida K, Terao J: Macrophage as a target of quercetin glucuronides in human atherosclerotic arteries: implication in the antiatherosclerotic mechanism of dietary flavonoids. J Biol Chem 2008, 283: 9424-9434.

33. Young JF, Nielsen SE, Haraldsdottir J, Daneshvar B, Lauridsen ST, Knuthsen P, Crozier A, Sandstrom B, Dragsted LO: Effect of fruit juice intake on urinary quercetin excretion and biomarkers of antioxidative status. Am J Clin Nutr 1999, 69: 87-94.

34. Manach C, Williamson G, Morand C, Scalbert A, Rémésy C:
Bioavailability and bioefficacy of polyphenols in humans. I. Review of 97 bioavailability studies. Am J Clin Nutr 2005, 81: 230-242. 